\title{
Magical mantle
} tour

\section{地球深部の 謎を解く}

Nature Vol.440(1108-1110)/27 April 2006

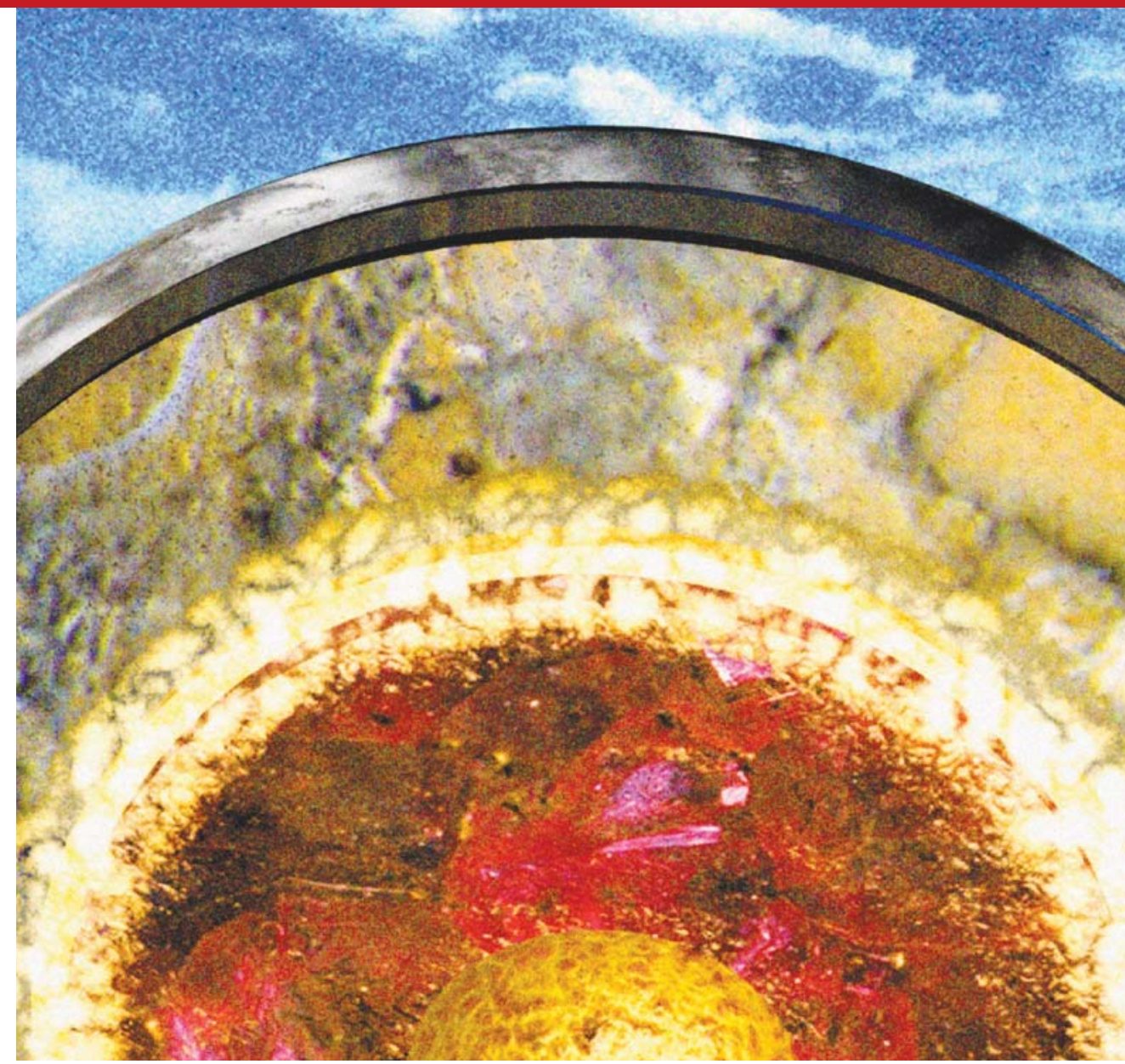

日本人研究者が最近発見した結晶構造は、地球の奥深くで起こっているさまざまな現象を説明するとみられる。地球物 理学者たちは、この結晶構造をさらによく理解しようと必死だ。David Cyranoski が取材した。

そこは、あらゆることがおかしくなる 不思議な場所だ。地下約 2700 キロメー トルの地球内部。固体マントルと液体 である外核 (地球の核のうちの外側部 分）の境界のすぐ上にあるその層では、 地震波が奇妙なふるまいをする。一部 の地震波は一定速度で進み続けるので はなく、その領域へ入る際に加速し、 いったん内部へ入ると今度は進行方向 によって速度を変える。一部の小さな 領域では、地震波の速度が 30 パーセン 卜も遅くなることもある。

こうした地震波は、科学者たちが地球 の深部を探るための主たる手段だ。地球 内部で反射する地震波に関する研究から は、地球が地殼、マントル、外核、内核 の層になっていることがわかった。そして 「D"（ディーダブルプライム）層」とよば れるのが上述の問題の層である。だが、
この層で地震波がみせる奇妙なふるまい の原因はいったいどこにあるのだろうか。

最近まで、この疑問にどう答えれば よいのか誰もわからなかった。リバプー ル大学（英国）の地震学者Christine Thomasは「2、3 年前は地球深部の 地震学は停滞しているように思えた」 と話す。そうしたなかで、東京工業大 学大学院の廣瀬敬が率いる研究グルー プは 2004 年、マントル最深部の圧力 と温度を実験室で再現したことを報告 した (コラム「2つの発見物語」参照)。 そして廣瀬たちは、マントル最深部に 豊富にあるとみられる鉱物、ケイ酸マ グネシウム $\left(\mathrm{MgSiO}_{3}\right)$ が、これまで知 られていなかった結晶構造をとること を発見した $1 。$

この構造は $\mathrm{MgSiO}_{3}$ の「゚ストペロ フスカイト相」といい、ありふれたペ
ロフスカイト構造と同じ化学組成をも つが、原子の並び方が異なっている。「ポ ストペロフスカイトはより密で、3 次元 の結合構造をもつペロフスカイトと比 ベると、2 次元のシートを重ねたような 構造になっている」と廣瀬は説明する (右ページ図を参照)。こうした原子配 列の変化は相転移の一種だが、これが 地球の下部マントルでの地震波の異常 なふるまいを説明づける可能性がある。

\section{さまざまな物質に見つかる}

相転移は地質学ではありふれたことで、 廣瀬が見いだした真相も聞く人によって はがっかりするかもしれない。ロンドン 大学ユニバーシティカレッジの鉱物物理 学者John Brodholt は、「我々がここ何 年も探してきたものが、相転移にすぎな かったとは」と話す。しかし、ポストペ 
ロフスカイト相の発見は地震学や地球力 学、鉱物物理学の分野を活気づけた。

廣瀬の論文が巻き起こした興奮の中 で、研究者たちはポストペロフスカイ 卜構造の特性や、この構造によって解 明される可能性があるその他の地震学 的謎、また、マントル內の熱の流れに おけるこの構造の意味について議論し た。惑星科学の専門家たちは、ポスト ペロフスカイト構造の発見をふまえ、 地球の自転速度の変動原因を再検討し ているほか、地球以外の惑星の特徵に ついてもこの構造で説明できないかと 考えている。スイス連邦工科大学チュー リッヒ校の結晶学者Artem Oganov は 「理論家として私たちは、実験から得ら れる手がかりを待っていた。この構造 の発見は大きな刺激となった」と話す。

廣瀬のグループによる最初の発表 後、鉱物物理学者たちは実験と理論の 両面からポストペロフスカイト構造 の $\mathrm{MgSiO}_{3}$ の存在および構造を確か めた 2,3,4。そして研究者たちは、ケイ 素の場所にゲルマニウムがあるゲルマ 二ウム酸塩など、ほかの鉱物について も調べた。すると、そこにもポストペ ロフスカイト構造が見つかった。プリ ンストン大学（米国ニュージャージー 州) の地球物理学者Thomas Duffy は 「これまで誰もこの構造を見つけていな かったことが驚きだ」という。

ポストペロフスカイトによって、長年 の謎の多くが明らかになるようだ。たと えば、Brodholtたちはシミュレーショ ンを使い、S 波とよばれる地震波が、D" 領域中のある場所でなぜ突然加速するの かという疑問に取り組んだ。また、S 波 の D" 領域中でのふるまいは、別種の地 震波である粗密波（P波）とも異なって いる。もし、その領域がペロフスカイト ではなくポストペロフスカイトを含むな ら、両方の観測結果はポストペロフスカ イトの特性によるものといえるだろう5。

同様にポストペロフスカイトは、D" 領 域中を進む S 波が方向によって速度を変 える理由も説明できる。これは地震波の「異 方性」とよばれる現象だ。ポストペロフス
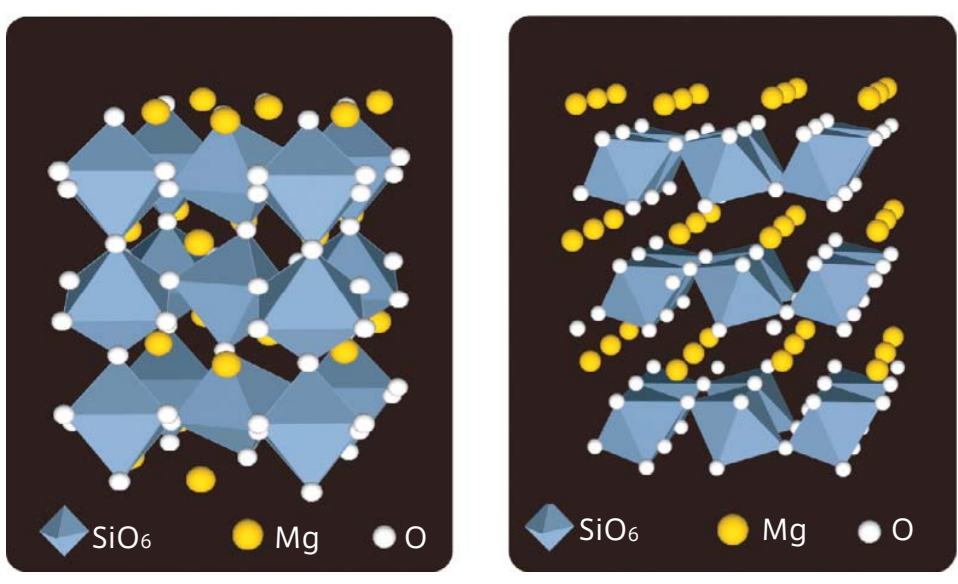

ペロフスカイト (左) とポストペロフスカイトの構造 (右)。

カイトの原子の並び方の向きにより、S 波 はある決まった軸に沿って結晶中をより速 く進む。D" 領域での地震波観測結果の異 方性パターンは、これで説明される ${ }^{6,7}$ 。

\section{深まる謎}

「こうした原子レベルでの研究は、地球 科学におけるさらに大きな疑問を解明す る。たとえば、熱や岩が地球深部から地 球表面へ向かってどのように流れるかと いった問題だ」と廣瀬は話す。ペロフス カイトがポストペロフスカイトに変わる ときに結晶格子構造がどう変化するかを 理解すれば、下部マントル中の流れの速 度と方向を知ることができる。

ポストペロフスカイトはさらに、マン トルを対流させる巨大なエンジンを動 かしている、もうひとつの動力源なのか もしれない。マントルの比較的低温の領 域では、相転移は圧力が低い、つまり深 さが浅いところで起こる。周囲の高温領 域と比べると、新たにできるポストペロ フスカイトは温度が低いだけでなく、密 度も高くなり、これがポストペロフスカ イトの沈み込みのもう 1 つの理由とな る。カリフォルニア大学サンタクルーズ 校の地震学者Thorne Lay は「相転移は、 対流を後押ししている追加ポンプのよ うなものだ」と話す。

もし、ポストペロフスカイトが地球 内部の力学において本当にそれほど重 要なら、この新しく発見された構造は 大きな成功といえるだろう。しかし今
のところ、ポストペロフスカイトによっ て解明された謎よりも多くの疑問が新 たに生まれているようだ。

たとえば、地震波の異方性にポストペ ロフスカイトが果たす役割に関する研究 のすべてで、結晶構造がどう変形するか の予測が食い違っている。研究者たちは、 正しい変形パターンと自身のモデルが合 わなければならないことを理解している が、そもそもどの変形パターンが正しい のかがまだわかっていないのだ。

相転移が起こる圧力と温度の関係も 正確には解明されていない。相転移は 特定範囲の圧力と温度で起こり、より 高温では高圧力が必要だとわかってい る。しかし、圧力のデータは実験に使 われた装置によって 15 ギガパスカル もの違いがある。これは深さに換算し て 350 キロメートルの違いに相当する。 廣瀬は昨年 10 月、東京で開かれたポス トペロフスカイトのワークショップで 「不確かさの最大の要因は、装置による 圧力の食い違いだ」と話した。

\section{地球の自転速度にも影響 ?}

スイス連邦工科大学チューリッヒ校の理 論モデル作成者 Paul Tackley は「D" 領 域では温度が大きく変化することを考え ると、ポストペロフスカイトがどこに現れ るかを知るのはむずかしい」と話す。彼 が行ったシミュレーションによると、約 $3200^{\circ} \mathrm{C}$ の比較的熱い領域にはポストペロ フスカイト相はないだろうという８この 


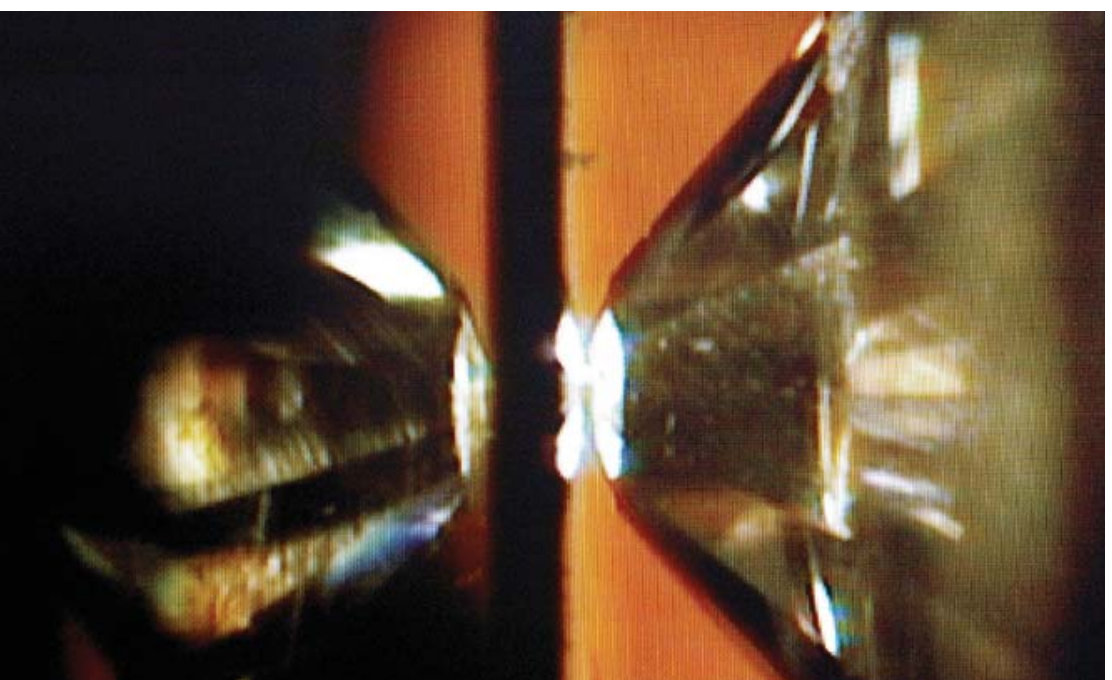

プレッシャーのもとで : ダイアモンドアンビルは地球深部の高圧を再現する。

温度は、マントルと同程度の深さのほか

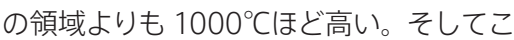
の比較的熱い領域では、マントルプルー ムが生じると考えられている。マントル プルームは地球の深部から上昇する上昇 流で、熱と岩の巨大な道筋となり、地球 表面では火山のホットスポットとして現 れていると多くの研究者が考えている。 地球の力学に関係する、ある重要な 問題についても大きな疑問が残ってい
る。地球の核を構成する液体の鉄は、 マントルとどの程度相互作用している のかという問題だ。鉄原子は、 $\mathrm{MgSiO}_{3}$ のマグネシウムの一部と置き換わるこ とができる。シカゴ大学（米国イリ) イ州）のWendy Mao は、まさにどれ だけの鉄をポストペロフスカイトが取 り込むかを測定した。

その結果 Maoは、ポストペロフス カイトがこれまで知られていたどの下
部マントル材料よりもずっと多くの鉄 を取り込むことを発見した ${ }^{9}$ 。「鉄はポ ストペロフスカイトにおいて支配的で、 きわめて複雑な役割を果たしているの かもしれない」と彼女は話す。鉄吸収は、 マントル底部の特定の小領域における 地震波の劇的な減速に関しても説明で きるかもしれない。しかし、鉄が含ま れる場合はペロフスカイトがポストペ ロフスカイトへと変わる圧力の範囲も 広がり、相転移が起こる境界を正確に 定めるのはさらにむずかしくなる。

こうした問題は、ポストペロフスカイ トのふるまいに関する単純なモデルで複 雑な領域を理解しようとしているために 生じるのかもしれないとLay は指摘する。 彼は、「ポストペロフスカイトの性質に関 する見積もりのすべてが数值モデルに基 づいていることが大きな問題だ」という。 そして、さまざまな要素が複雑に関与す る領域について、「数值モデルが本当に 妥当であるかは明らかではない」と話す。

D" 層の詳細は明解になるというより、 さらに複雑になってしまいそうだ。「当初 はポストペロフスカイトがすべてを説明 するかもしれないという興奮があった。

\section{2 つの発見物語}

ポストペロフスカイト構造の $\mathrm{MgSiO}_{3}$ は、長く待ち望まれた 発見だった。その発見はどのよ うに行われたか。答えはだれに 尋ねるかによって変わってくる。

廣瀬敬と小野重明は、かつ ては協力して研究していた。 しかし、今は廊下での丁寧な あいさつを除いて言葉を交わ すことはない。

2 人はともに東京工業大学の 1 階離れた階で研究している。 廣瀬は同大学の教授であり、小 野は海洋研究開発機構の研究員 で、別の科学者と協力している。 廣瀬と小野は同じような研究に 取り組んでいる。ダイアモンド
アンビルとよばれる装置を使っ て 2 つのダイアモンドの間で材 料を締めつけ、レーザーで加熱 する。2 人とも、地球の内部を 模した極端な高圧下で材料の性 質がどのように変化するかを測 定している。

廣瀬も小野も、鉱物 $\mathrm{MgSiO}_{3}$ のポストペロフスカイト相の発 見に重要な貢献をした。しかし、 廣瀬が昨年 10 月、ポストペロ フスカイトに関する会議を東京 で組織したとき、小野は講演者 として招待されなかった。

廣瀬は社交的で話好きの快 活な性格だ。昨年 10 月には、 米国・ワシントンDC のカーネ
ギー研究所でポスドク特別研 究員だったときに覚えた自信 に満ちた英語でワークショッ プを指揮した。対して小野は 日本語での取材を望み、内気 で生まじめ、控え目な性格だ。

しかし彼らの不信は、単な る個性の不一致から生まれた のではない。2人はそれぞれの 「ポストペロフスカイト発見物 語」をもっている。

2 人とも、技術の進歩が道 を開いたという点では同じ意 見だ。1987 年に発表された論 文を基に、 $\mathrm{MgSiO}_{3}$ のペロフ スカイト相はマントルの底近 くの圧力下でも安定だとほと

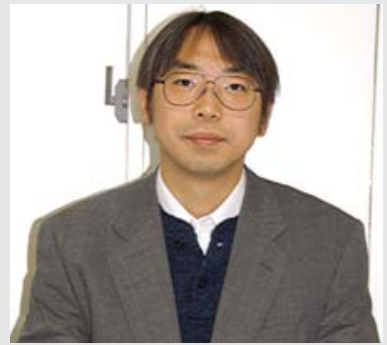

廣瀬敬教授 : 廣瀬は「小野はいつ も内容を隠して研究を進めていた」 と話す。

んどの研究者が信じたと廣瀬 はいう ${ }^{11}$ 。だから、ポストペ ロフスカイトを探す価值はほ とんどないように思えた。「実 験を試みた者は多くなかった。 
しかし、研究者たちは今、その性質を冷 静に見つめ直している」とMao は話す。

不確かなことは残っているが、研究者 たちは新しい研究領域へと突き進んでい る。海洋研究開発機構 (本部・神奈川県 横須賀市) の小野重明は、 $\mathrm{MgSiO}_{3}$ が地 球のある謎を解く可能性について調べて いる。「地球の自転は 10 年の期間でみて 数ミリ秒、加速·減速している」と小野 は話す。核とマントルの電磁的な結合が これを引き起こしているという仮説があ るが、もしそうであれば、下部マントル の電気伝導率は高くなければならない。 ペロフスカイトの伝導率は高くないので、 下部マントルが (多くの科学者が考えて いたように）主にペロフスカイトででき ているならばこの仮説は成り立たない。

しかし小野は、ポストペロフスカイト 構造の $\mathrm{Al}_{2} \mathrm{O}_{3}$ （ポストペロフスカイト構 造の $\mathrm{MgSiO}_{3}$ よりも性質がよくわかっ ている酸化アルミニウム) の電気伝導率 が高いことを発見した。彼は、ポストペ ロフスカイト構造の $\mathrm{MgSiO}_{3}$ もおそらく $\mathrm{Al}_{2} \mathrm{O}_{3}$ と同じ特性の多くを備え、地球の 自転速度の変動を説明するのに十分なほ どに高い電気伝導率をもつと主張する。
「これはポストペロフスカイトが新たに説 明する、地球の謎の 1 つだ」と小野はいう。

\section{ほかの惑星にも}

研究者の中には、ポストペロフスカイト 構造の $\mathrm{MgSiO}_{3}$ がほかの惑星でどのよう な役割を果たしているかを考えている者 もいる。ミネソタ大学ミネアポリスキャ ンパスのRenata Wentzcovitchたちは、 ガス巨星や、ほかの太陽系にある岩でで きた惑星の内部におけるポストペロフス カイトのふるまいをシミュレーションし た。そしてそうした高圧・高温の場所で は、 $\mathrm{MgSiO}_{3}$ はほとんど金属のようにふ るまい始めることがわかった ${ }^{10}$ 。

地球ではポストペロフスカイト層の 下の一部領域にペロフスカイトがある かもしれないという可能性があり、多 くの科学者たちが期待をふくらませて いる。これは、S波が最初は加速、次 に減速と 2 段階で速度を変えることを 示す地震波デー夕の説明となるだろう。 さらには、深さによる温度変化につい ても明らかになるかもしれない。「これ は下部マントルと核の一種の温度計と なるだろう」とThomasは話す。
廣瀬自身は今回の有用な発見につい て、もしかしたら研究者たちを困惑さ せているかもしれないとはいえ、よかっ たと思っている。ポストペロフスカイ トは D" 層の大部分については説明でき ないかもしれないが、その存在自体が 重要である。「ポストペロフスカイトの 割合はすごく大きくはないかもしれな い。しかしそれは、核とマントルの間 の温度的な境界であり、化学的な境界 でもある場所にある。地球に関するき わめて重要な問題を理解するのにポス トペロフスカイト構造はきっと役立つ はずだ」と廣瀬は話している。

DavidCyranoski は、Nature のアジア・パシフィック 担当記者。

1. Murakami, M. et al. Science 304, 855-858 (2004).

2. Oganov, A. R. \& Ono, S. Nature 430, 445-448 (2004).

3. Tsuchiya, T. et al. Earth Planet. Sci. Lett. 224, 241-248 (2004).

4. Shim, S. -H. et al. Geophys. Res. Lett. 31, L10603 (2004)

5. Wookey, J. et al. Nature 438, 1004-1007 (2005).

6. Oganov, A. R. et al. Nature 438, 1142-1144 (2005).

7. Merkel, S. et al. Science 311, 644-646 (2006).

8. Hernlund, J. W. et al. Nature 434, 882-886 (2005).

9. Mao, W. L. et al. Proc. Natl Acad. Sci. USA 101, 1586715869 (2004)

10. Umemoto, K. et al. Science 311, 983-986 (2006).

11. Knittle, E. et al. Science 235, 668 (1987).

12. Ono, S. etal. J. Phys. Chem. Solids 65, 1527-1530 (2004)
実験もきわめてむずかしいも のだった」と廣瀬は話す。

しかし、廣瀬は 2002 年までに、 5 年以上も前から心に描いてい た実験を行うことに成功した。 ペロフスカイト構造の $\mathrm{MgSiO}_{3}$ 試料を核 -マントル境界に近い 圧力と温度におく実験である。 彼は、大型放射光施設 SPring-8 (兵庫県佐用町) で試料を分析し た。そして、データの中に異常 な回折パターンを見つけた。

データの分析を手伝ってくれ る化学者を見つけるのに、何か 月もかかったという。「化学が 専門の教授たちは、データが 間違っているか、あるいは私が 間違っているに違いないといっ た」と廣瀬は振り返る。ようや く、東京工業大学の同僚で化学
者である村上元彦が、新年の 休暇にデータを分析する時間を とってくれた。そして村上は、 試料の中にポストペロフスカイ 卜構造を発見した。

しかし小野は、ポストペロ フスカイト発見への重要な段 階がその 6 か月以上前にあっ たと主張する。彼は鉱物の赤 鉄鉱 (ヘマタイト) に、廣瀬 が $\mathrm{MgSiO}_{3}$ に見つけたのと同 じ構造ができる、高圧での相 転移があることを発見し、そ れをポストペロフスカイトだ と考えた ${ }^{12}$ 。「私の目標は常に $\mathrm{MgSiO}_{3}$ だった」と彼は話す。

SPring-8を使っている研 究者たちは、共同使用のコン ピューターと公式のビームライ ンノートにデータを掲示するこ

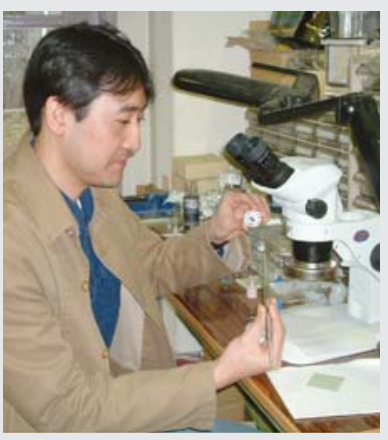

小野重明研究員 : 小野は、廣瀬が 自分をフェアに扱わなかったと感 じている。

とが求められている。だから、 廣瀬は自分の赤鉄鉱の研究を追 いかけることができたのだと小 野はいう。「これは完全に間違っ たことではないがフェアではな い。だから私は彼に協力するの
をやめた」と小野は話す。廣瀬 は小野について、「いつも内容 を隠して研究を進める」という。 2 人の同僚は彼らの不和につい てコメントするのを断っている。 2 人の不和は、多くの研究者 がかかわり、長く待ち望まれて いた発見がなされるような場 合にはつきものの出来事だった のかもしれない。理論家たち は 1999 年までに、地球内部の D" 領域での異常なふるまいを 説明する特性をもつ相転移をす でに明確に予測していた。ロン ドン大学ユニバーシティカレッ ジの John Brodholt は「それ はきわめて正確な予測だった。 つまり、その予測にとって必要 なのは実験的な証拠だけだっ た」と話している。

D.C. 